\title{
What is the evidence base for integrating health and environmental approaches into the school context to nurture healthy and environmentally aware young people? A systematic scoping review of global evidence
}

\author{
Rachel Proctor ${ }^{\mathrm{a}} *$ Cornelia Guell ${ }^{\mathrm{a}}$, Katrina Wyatt ${ }^{\mathrm{b}}$, Andrew James Williams ${ }^{\mathrm{a}, \mathrm{c}}$ \\ ${ }^{a}$ European Centre for Environment \& Human Health, University of Exeter Medical \\ School, Truro, UK \\ ${ }^{\mathrm{b}}$ Institute for Health Research, College of Medicine and Health, University of Exeter, UK \\ ${ }^{c}$ Division of Population and Behavioral Science, School of Medicine, University of St \\ Andrews, UK
}

\begin{abstract}
This scoping review collates empirical and grey literature that examines how schools are acting to nurture healthier and more environmentally aware young people through integrated approaches. Over the last twenty years, integration has been increasing within school contexts. Approaches include teaching and learning, physical environmental adaptations, developing ecologically focused policy, and reorienting wider school culture. We noted a developing discourse around what constitutes evidence in this emerging interdisciplinary field. Developing a better understanding of integrated approaches, and an evidence base of what works and how, could inform interdisciplinary collaboration and enable a clearer message to be communicated to stakeholders about how the school context can nurture healthier and more environmentally aware young people.
\end{abstract}

Key Words: education; health; sustainability; environment; school; scoping review

\section{Background}

Society is increasingly experiencing "wicked problems" associated with human health and environmental change (Head \& Alford, 2015). Global research agendas such as "Planetary Health" (Rockefeller Foundation, n.d.) and "One Health" (WHO, 2019) are 
emergent frameworks through which we can rethink public health in a period of unprecedented environmental and societal change. Increasing rates of noncommunicable diseases (NCDs) such as type 2 diabetes mellitus, cancers, cardiovascular diseases, and mental health conditions are often influenced by upstream human behaviors that also feature in cycles of environmental degradation (King's Fund, 2013). For example, a reliance on environmentally inefficient modes of transport has led to poor air quality and increasing rates of respiratory conditions (WHO, 2005a). Patterns of overconsumption have led to an obesity syndemic and have influenced (and are influenced by) environmentally unsustainable agricultural practices (Hawkes, 2007; Berners-Lee, 2019; Swinburn et al., 2019). Current and future generations are faced with mitigation and adaptation in response to these issues, which will require a critical awareness of the relationships between human behavior, human health, and the health of the environment (The Rockefeller Foundation, 2019; WHO, 2017).

Many health and environmental behaviors are shaped in early life (Frech, 2012), and given that $91 \%$ of the world's primary school-age population are in some form of mainstream education (UNICEF, 2018), the school context is an important place in which to support human health and the environment (Halfon \& Hochstein, 2002). Schools have long played an important role in public health (Harris, 1995). Their importance as places with the power to influence health behaviors was recognized in 1986, when the World Health Organization's Ottawa Charter for Health Promotion and the subsequent Health Promoting School framework were launched (WHO, 1986).

Research has also highlighted the importance of using multilevel approaches to make the greatest gains from health promotion. Research conducted by West, Sweeting, and Leyland that examined young people's rates of health-related behaviors across 43 UK secondary schools found that "schools which succeed in engaging pupils with 
education which promote pupil involvement, and have better teacher-pupil relations, are more likely to secure pupil attachment to the goals of health promotion" (pp. 286-287). A systematic review of the associations between obesity and primary school diet and physical activity policy found that "complex approaches to preventing childhood obesity which focus on multiple factors (e.g. diet, physical activity, sedentary behavior, self-esteem) and at multiple levels of influence (e.g. home, school, neighborhood)" are necessary for an optimal and sustainable impact in the longer term (Williams et al., 2013, p. 19). Developing a better understanding of approaches that support schools and communities to develop a health-promoting ethos and influence health behaviors remains critical.

Although less well-established in schools, the concepts of ecologically friendly or sustainable schools have sought to influence environmental awareness and related behaviors in young people (Harris, 2008; Eco Schools, 2020). An increasing body of research has examined how the principals involved in Environmental Education and Education for Sustainable Development can facilitate better environmental outcomes and nature stewardship in children (Kahn \& Kellert, 2002; King \& Kahn, 2003; Eames et al., 2008). While both of these approaches seek to influence environmental knowledge and behaviors, they are also conceptually distinct. Environmental Education has historically been associated with ecology and conservation and is often grounded in traditional scientific literacies, while Education for Sustainable Development, a term advocated for by UNESCO, integrates social, cultural, and economic facets of sustainability. Across both approaches, differing underlying paradigms shape the problematization of environmental issues, influencing how existing beliefs regarding the nature of human relationships with the planet are sustained or challenged (Jickling, 
2001; Simpson \& Freeman, 2004; Jickling \& Wals, 2008; Kopnina, 2012a; Bacchi, 2016).

Nature connectedness, another diverse and contested term, is being seen as increasingly important in terms of community- and school-based health and environmental approaches (Kaplan \& Kaplan, 1989; Kellert \& Wilson, 1993; Maller et al., 2006*). Community gardens based in school settings have been associated with positive impacts on physical activity levels, wellbeing, and social connection (Lovell et al., 2014; Ohly et al., 2016), while free play in natural environments has been positively correlated with increased empathy and connection to nature (Louv, 2010; Kemple et al., 2016).

For health-promotion strategies in the school context, examining how and why connection to nature plays a role in wellbeing and how nature-based approaches can be fostered through social practices has begun to shape the development of natureinformed pedagogies, such as storied landscapes (Jrgensen, 2017) and narrative journeys (Waters, 2017). Research exploring the role of democracy, agency, and participation has aimed to explore children's attunement to nature from "contemporary sociological understandings of children's competence as social actors" (Holloway \& Valentine, 2004, p. 2). There is increasing concern that young people are experiencing a nature deficit that is associated with changing cultures of play and increased technology use, and addressing this is seen as important for educators, researchers, and policy makers alike (Louv, 2010; Kemple et al., 2016; MacQuarrie \& Nugent, 2017).

The role and function of science education, which is intertwined with health, environmental, and sustainability education, has also evolved in many countries. Understanding the "mutual inter-dependence" (Dillon, 2012; Zeyer \& Dillon, 2014) between problems related to health, the environment, and science has fostered critical 
discourse around the evolving characteristics of science education and engaged citizenship (Zeyer \& Kyburz-Graber, 2012). Broadly, socio-scientific problems require the teaching and learning of a wide range of scientific processes and technical skills that draw on economic, sociological, philosophical, and ethical components that contextualize science for learners by fostering a coherent thread through place, connection, and action (Barton \& Upadhyay, 2010; Buxton, 2010). Evidence exploring the implications of these multifaceted issues and how they can be approached in ways that build on the synergies between health, the environment, and sustainability has shaped several strands of thinking. It has had a particular influence on how the future of engaged science literacy will reflect "what is important to know, value and be able to do" (Bybee, 2012, p. 49) in terms of issues relating to health, the environment, and science. Moreover, the way in which socio-scientific problems require a diverse citizenship, competent out-of-the-box thinking, innovative design, and creativity (including the expressive arts) has implications for education more broadly regarding how it can evolve to build and foster the resilience necessary in young people to adapt to unprecedented social and climate change (Kagawa \& Selby, 2010; Anderson, 2012). In many cases, governmental policy has begun to advocate for more holistic action in response to environmental issues. In the UK, for example, between 2004 and 2010, the Sustainable Development Commission (SDC) and the Department for Education (DfE) developed a National Framework for Sustainable Schools, a holistic approach to environmental sustainability that spanned "curriculum, campus and community" (DfE, 2009). An evaluative report found that schools focused on sustainability encouraged "students to become more readily engaged in the complex issues and dilemmas of sustainability" and that students showed increased "participation and enthusiasm," which are key components of effective learning (Birney \& Reed, 
2009, p. 5). Although the National Framework for Sustainable Schools lost political support, voluntary initiatives such as "Eco-schools," "Nature Friendly Schools," and "Forest schools" are acting to nurture healthier and more environmentally aware behaviors for primary school-aged children. From an international perspective, similar approaches such as "Enviroschools" in New Zealand (Toimata Foundation, 2020), "Green schools" in the USA (Green Schools Alliance, 2020), and "Skovbørnehave" (forest kindergarten) in the Danish context are gaining recognition.

It is clear that health-promoting and sustainable school initiatives and health, science, and environmental education share many approaches and seek similar outcomes, including fostering healthy and sustainable knowledge and behaviors; cultivating wellbeing, resilience, and innovation; developing children's capacities to think critically; and developing other health and scientific literacies. Furthermore, with recent calls for a "realignment of health-promotion research agendas to address environmental challenges in, with and through schools" (Dadaczynski, et al., 2019, p. 3), understanding more about the potential role of integration in supporting healthy and environmentally aware behaviors is important.

We therefore conducted a systematic scoping review (Arksey \& O’Malley, 2005; Tricco et al., 2018) to collate and map the academic, empirical, and grey literature associated with healthy green integration in the mainstream school context. The overarching research question was as follows: what is the evidence base for integrating health- and environmental-related approaches in the school context to nurture healthy and environmentally aware young people? Our aims were to collate and map the extent and range of evidence geographically, by feature of school environment, and to identify gaps. 


\section{Methods}

The systematic scoping review followed the guidelines within the PRISMA-ScR: checklist and explanation (Tricco et al., 2018), which built on the previous work of Arksey and O’Malley (2005) and Colquhoun and colleagues (2014). The revised guidance includes 27 steps for robust reporting of scoping review data. We developed an initial review protocol to ensure the clarity and comprehensiveness of the review process (which can be requested from the corresponding author).

\section{Search terms and language}

Initial scoping of relevant databases in education, health, and social sciences revealed both commonalities and differences in the terminology used to define health promotion and environmental sustainability approaches applied in the school context. In the interest of using a broad and globally recognized definition of health promotion in relation to the school context, we utilized the World Health Organization's Ottawa Charter for Health Promotion, which states:

Political, economic, social, cultural, environmental, behavioral and biological factors can all favor health or be harmful to it. Health promotion action, aims at making these conditions favorable through advocacy for health. (WHO, 1986, p. 1)

Refining and choosing a definition of environmental sustainability was equally problematic because the way this is conceptualized varies across the evidence (Jickling \& Wals, 2008). During the initial scoping, the United Nations' Brundtland Report on Sustainable Development was cited in much of the environmental education literature. The report defines sustainable development as "development that meets the needs of the present without compromising the ability of future generations to meet their own needs" (UN, 1987, p. 16). We chose this broad and internationally recognized definition 
because it was commonly applied to initial evidence searches, although we remained conscious of the contentious nature of how environmental education and environmental sustainability education are defined depending on the paradigmatic boundaries in which they are conceptualized (Bonnett, 1999; Jickling \& Wals, 2008). In the light of our objectives to map the extent and range, rather than appraise or critique evidence, at the stage of inclusion and exclusion, we took an inclusive approach to studies that utilized other definitions but met all other criteria.

We developed a comprehensive string of search terms (English language only). Below is a full list of the search terms we applied.

health*, promotion, education, learning, awareness or behaviors (AND) enviro*, environmental or environment (AND) school* or schooling (AND) sustain*, sustainable or sustainability) (OR) green (OR) planetary (OR) eco*, ecology or ecological.

\section{Searches}

Search strings were applied across ten peer-reviewed health, education, and social science databases: PubMed, Medline, Web of Science, British Education Index, Australian Education Index, Education Research Complete, Campbell Systematic Reviews, Prospero, the Kings Fund Digital Archive, and the Education Resources Information Centre. Supplementary searching was conducted through topical and systematic review databases, and hand searching and forward citation searches were also done. Grey literature was identified through comprehensive searching of online platforms (SEEd, 2019) and common search engines. We searched academic and UK school websites for pertinent maps, articles, commentaries, and systematic reviews as well as unpublished literature and theses in progress. The same search strings were applied consistently for the sake of coherence and reliability and we were interested in 
any source that had been published over a twenty-year period (spanning 1998-2018). Our primary searches took place between June and October 2018.

\section{Study selection}

\section{Inclusion and exclusion criteria}

To be included in the review, the source (whether empirical, theoretical, or grey literature) needed to focus on the mainstream school context providing educational provision for children aged 3-18 years. Articles that focused on the teacher-training environment were considered on an individual basis and retrieved for further scrutiny if at least two members of the review team saw the content as directly related to, or impacting upon, the school context (either through curriculum or by being directly related to classroom practice) (Elsden-Clifton \& Futter-Puati, 2015*; Mandikonza \& Lotz-Sisitka, 2016*). Populations of interest included children, teachers, management, kitchen workers, and any other role within the school, as well as families and wider school communities. The source was required to discuss an activity, policy, curriculum, ethos, or adaptation within the school context that sought to both improve and promote the health and wellbeing of its community, and had to explicitly state actions to be undertaken in order to improve environmental sustainability awareness or action. Any outcomes that were directly related to health and environmental sustainability were of interest to the research team, including health and behavioral indicators, learning, attitudes, and perceptions, and cleaner air quality or other measures of environmental quality that are linked to supporting health. In line with systematic scoping review methodology, no formal quality criteria for study design were used; rather, our aim was to capture a broad map of the literature that has explored how schools have acted or are acting to nurture healthier and more environmentally aware behaviors. 


\section{Screening}

All titles and abstracts were imported into Endnote software (2018) and reviewed against the inclusion and exclusion criteria. Ten percent of titles and abstracts were screened using a double blind approach by two reviewers (RP and AJW) to test the screening process. Texts for possible inclusion were retrieved and the full text reviewed and if appropriate selected for abstraction.

\section{Quality assessment}

Due to the broad methodological approach undertaken, no formal process of quality appraisal, such as CASP (2018), was undertaken. This is standard practice in forms of evidence synthesis (such as scoping reviews) where the broad objective is to map the evidence base and no formal meta-analysis or in-depth synthesis is undertaken.

\section{Data abstraction, charting, and synthesis}

Selected texts went on to data extraction (see supplementary file). Data was abstracted and then charted in terms of the following descriptive characteristics: location and time of publication, type of evidence, focus of approach, source type and name, study design, the search method used to identify the source, and any other pertinent detail, such as whether empirical, conceptual, grey literature or another type of literature (see Summary of mapped literature in the Results section). Secondly, we undertook a narrative synthesis of these approaches, which included examining gaps in knowledge as well as of any underlying theoretical frameworks and reported impacts. 


\section{Results}

\section{Summary of mapped literature}

The first part of the Results section provides a summary of the mapped evidence that has explored how schools have acted or are acting to promote healthier and more environmentally aware behaviors. This map represents literature from across the globe published between 1998 and 2018 and includes academic articles, empirical studies, books, and a range of grey literature, including policy and online sources.

\section{Number and types of texts}

After the removal of duplicates, 3,051 titles and abstracts were screened and 228 papers underwent full text screening. During this process, a further two books that met the inclusion criteria were found by undertaking citation searches of included texts. A total of 87 sources were included in the systematic scoping review (all sources can be found as a supplementary file). This literature included journal articles $(n=75)$, books $(n=5)$, a thesis $(n=1)$, and additional grey literature sources $(n=6)$ that included reports, policies, and school philosophies. Throughout the review, sources that met our search criteria are distinguished with a *. Figure 1 shows the process of capturing the relevant literature using an adapted Preferred Reporting Items for Systematic Reviews and Meta-Analyses PRISMA flowchart (Moher et al., 2009). 


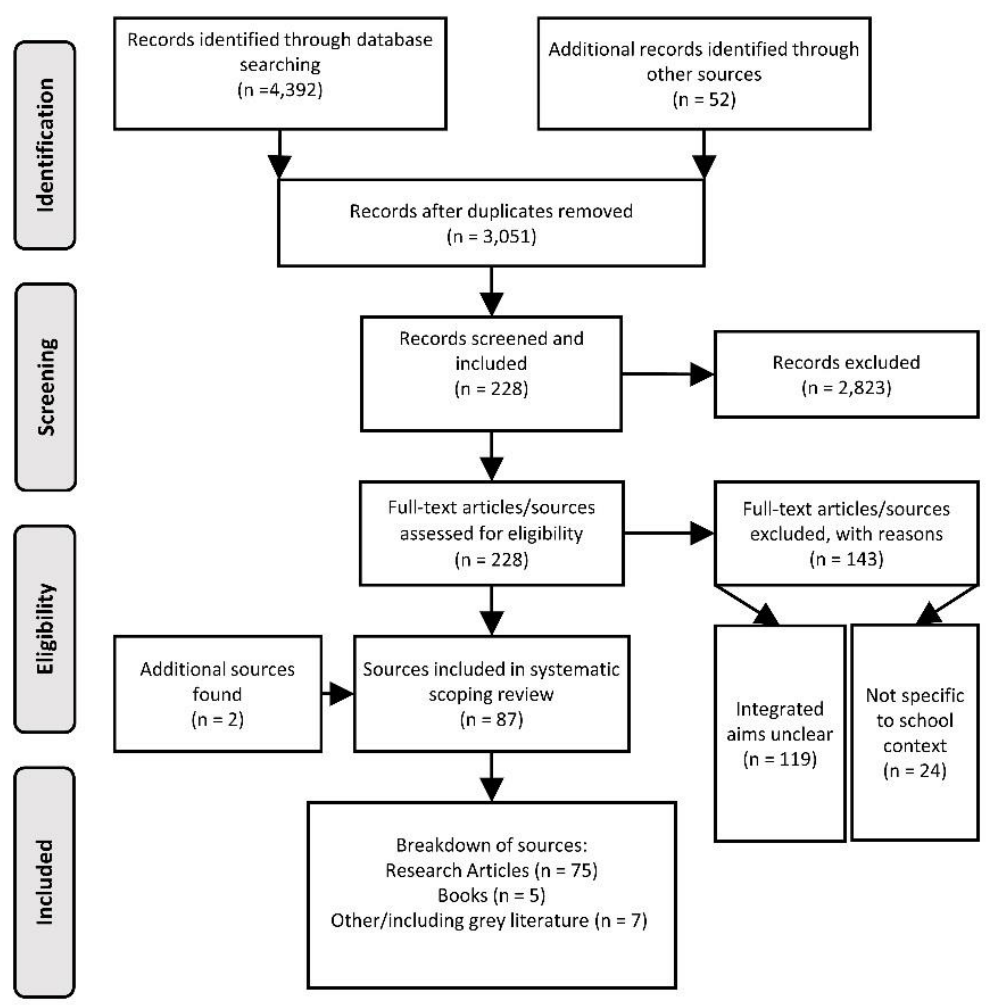

(Figure 1: Flowchart of search process adapted from the PRISMA Framework)

\section{Volume and timings of publications}

We found an increase in the overall volume of literature published over the last twenty years, with some spikes in volume during 2005, 2008, 2011, and 2016 (see Figure 2). The most significant drop in publications was found during 2017, although we found evidence that this fall stabilized in 2018 , with literature being more consistently published during this year. The evidence captured in this review was found to be fragmented, with several aspects of integration in the school environment underexplored. 


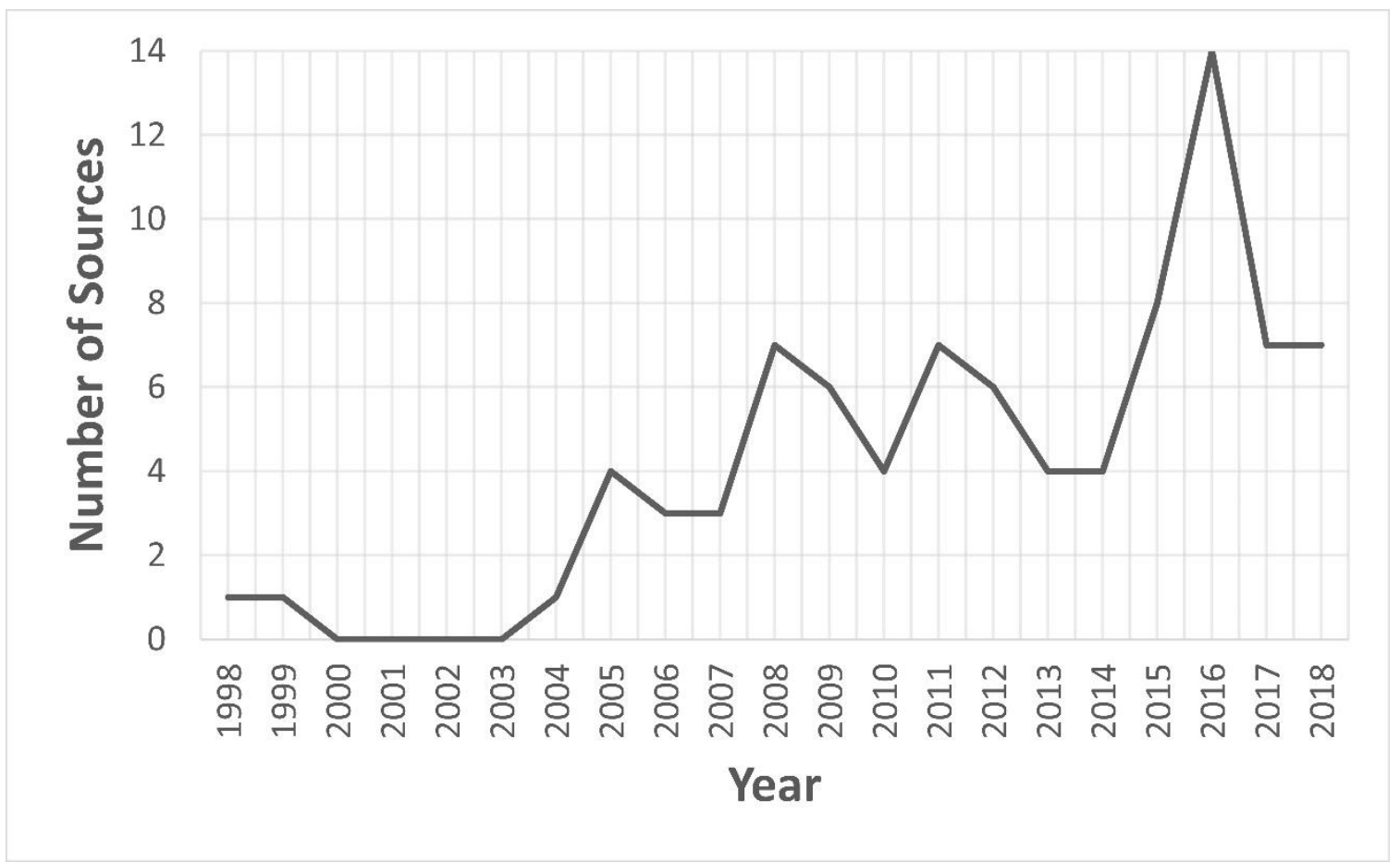

(Figure 2: Volume and timings of literature)

\section{Locations}

The texts located through the search represent a wide range of geographic regions

(Figure 3). Globally, the regions with the greatest volume of publications were North America $(n=35)$ and Australasia $(n=16)$. Africa and South America were found to have the smallest percentage of literature associated with integration, although we recognize that using English language search terms may have missed sources published in other languages. A key publication source was the Danish School of Education, which has published the most comprehensive and collated evidence around the rationales and strategies for schools to cultivate healthier and more environmentally aware behaviors (Simovska \& Mannix McNamara, 2015*). 


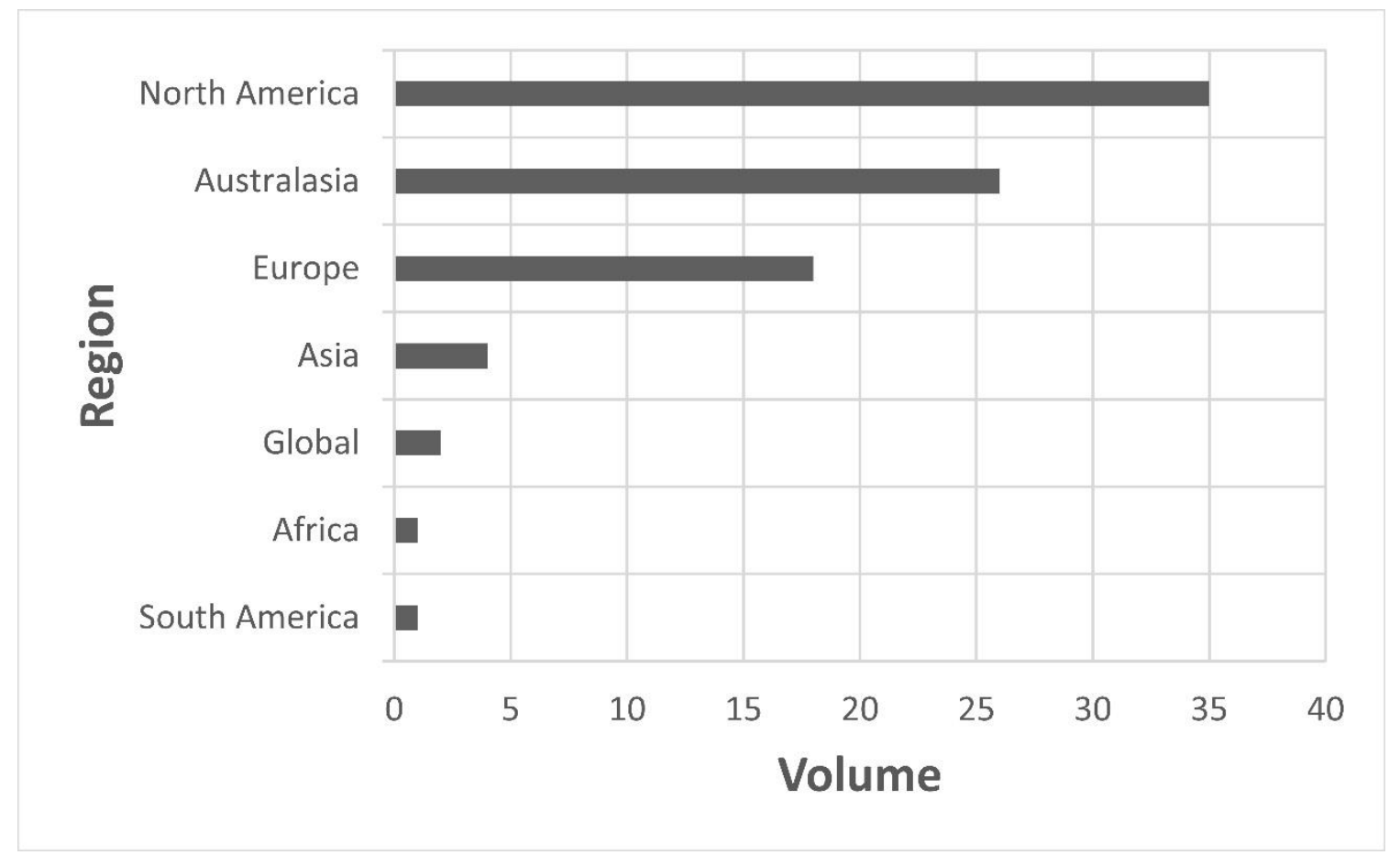

(Figure 3: Volume of evidence according to region)

\section{Approaches and activities}

The scoping review suggests that the most common approaches that schools use to improve rates of healthy and environmentally aware behaviors are as follows:

- Teaching and learning (developing action-competent young people; placebased learning)

- Use of physical environment (cultivating outdoor multi-use space and improving the built environment)

- Developing ecologically focused policy

- Through whole-school approaches (a focus on embedding a healthy and environmental ethos)

Figure 4 shows the focus areas from the evidence presented, which is based on empirical or theoretical research (75 academic journal articles). 


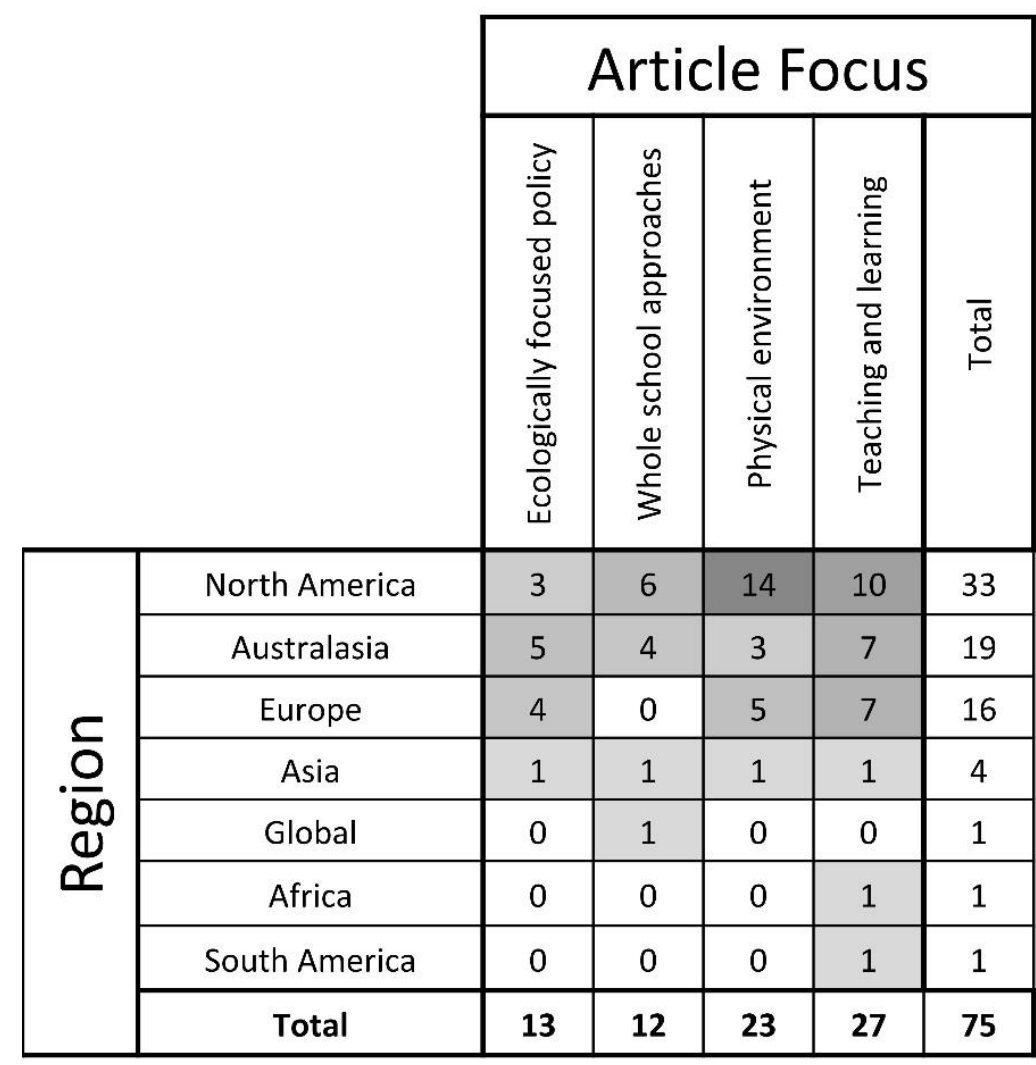

\begin{tabular}{|c|c|}
\hline 0 & $Z$ \\
3 & 0 \\
6 & \\
9 & $\mathbb{D}$ \\
12 & $\frac{7}{D}$ \\
15 & D \\
\hline
\end{tabular}

(Figure 4: Number of sources according to focus and region)

The strategies discussed were often dependent on other strategies being in place and on particular conditions related to the case study school or regional policy influences that affected how the school was able to operate. However, we collated the evidence under the categories above to map how schools have attempted to combine approaches to nurture healthier and more environmentally young people and to broadly highlight areas for future inquiry. 


\section{Teaching and learning}

Teaching to promote health and sustainability was implemented in two key ways:

(1) Developing children's action competencies (broadly, an individual's ability to solve problems using a range of resources, both independently and as part of a group or wider society) (Barrett, 2006*; Eames, Cowie, \& Bolstad, 2008*;

Enviroschools, 2017*; Langford et al., 2015*; Lysgaard \& Simovska, 2016*; Simovska \& Mannix McNamara, 2015*)

(2) Utilizing place-based approaches (through visits to natural environments or using places such as school gardens to teach children about sustainability, nutrition, and the value of green spaces in fostering mental wellbeing) (CutterMackenzie, 2009*; Edwards et al., 2016*; Maller \& Townsend, 2006*; Pryor, Carpenter, \& Townsend, 2005*).

\section{Developing action-competent young people}

One of the most prominent areas of teaching and learning found to be associated with health and environmental integration was the concept of action competence. Although diversely conceptualized in the critical literature (Jensen \& Schnack, 1997; Breiting \& Mogensen, 1999), there were some commonalities in how action-competent approaches to learning about health and environmental sustainability were described across the literature included in this review; these approaches were primarily described as fostering children's capacities to make meaningful connections (Barrett, 2006*). These connections were made through planning activities that were centered on a problem that encompassed features of both health and environmental sustainability. In this process, learners are often supported in making connections through targeted questioning and guidance on how to utilize appropriate resources to make systematic and achievable 
plans to solve problems, and this approach often draws on children's prior experiences across multiple subjects (Simovska and Mannix McNamara, 2015*).

Several articles explored how developing cross-curricula projects that integrated health and environmental education fostered problem solving, strengthened children's skills in group work, and developed independence and agency (Keselman et al., 2012*; Zimmerman \& Weible, 2017*). Action-competent approaches to learning were not found to be dependent on having access to green space, but rather on discrete approaches that centered on the quality of teacher-led facilitation, such as the use of directed, thought-provoking questioning, well-planned activity, and periods of supported and independent reflection (Jóhannesson et al., 2011*; Eames et al., 2008*; Enviroschools, 2017*; Lysgaard \& Simovska, 2016*; Simovska \& Mannix McNamara, 2015*; Enviroschools, 2019; Davis and Cooke, 2007*; O’Brien and Howard, 2016*).

\section{Place-based learning}

The second form of learning characterized as useful in promoting health and environmental sustainability was 'place-based,' 'hands-on,' or 'bush' learning (Green, 2013*; Madsen, Nordin, \& Simovska, 2016*; Maller \& Townsend, 2006*). These types of learning were described as experiences that centered on immersion in a natural environment. This immersion enabled students to engage in physical activity and environmental learning in an embodied and memorable manner that was found to be conducive to nurturing healthy and environmental behaviors. Forms of place-based learning were characterized in a number of ways, including 'Forest Schools' (Kemp \& Pagden, 2018*; L. O’Brien, 2009*), school gardens (Black et al., 2015*; CutterMackenzie, 2009*; Jones, Weitkamp, Kimberlee, Salmon, \& Orme, 2012*), 'bush therapy' (Pryor et al., 2005*), 'Enviroschools' (2017*; Jackson, 2009*), and, in the Danish context, udeskole (Waite, Bølling, \& Bentsen, 2016*). There were also 
examples across the literature of teachers combining action-competent approaches or other planned teaching approaches to strengthen the learning opportunities for children during place-based activities (Edwards et al., 2016*; Keselman et al., 2012*; Norðdahl \& Jóhannesson, 2016*; Turtle, Convery, \& Convery, 2015*).

\section{Physical environment}

\section{Outdoor}

Healthy and environmentally aware behaviors were also cultivated through 'greening' school playgrounds with additional planting (trees, herbs, flowers, and vegetable gardens). Strategies included ensuring that school grounds were as welcoming to nature as possible, including bees, birds, and other native species (Davis, Spaniol, \& Somerset, 2015*; Dyg \& Wistoft, 2018*; Enviroschools, 2017*; O’Brien \& Howard, 2016*). Cultivating space physically within the school or local community for gardens was found to increase children's awareness of environmental concerns and processes, while also offering the opportunity for school kitchens to cook healthier meals and increase children's nutrient intake alongside the teaching of farm-to-plate processes (Black et al., 2015*; Guitart, Pickering, \& Byrne, 2014*; Jones et al., 2012*; Kensler \& Uline, 2016*; Poland \& Dooris, 2010*; Rojas et al., 2011*). For schools without available space, visits to local nature reserves or other outdoor spaces were considered important to foster healthy and environmentally aware behaviors (Carley, Fisher, \& Ray, 2018*; Lewicki, 1998*; Zimmerman \& Weible, 2017*).

\section{Indoor}

Eco-friendly alterations to buildings such as improved ventilation and natural lighting were considered to be important characteristics of healthy and environmentally aware schools (Ahn, Choi, Koh, \& Pearce, 2011*; Ikeda et al., 2018*; Theodosiou \& 
Ordoumpozanis, $\left.2008^{*}\right)$. Many texts discussed the importance of recognizing the incongruence of schools teaching children how to undertake healthier and more environmentally aware behaviors when often the school building itself is not constructed in an environmentally sustainable way. Although this was seen to be related to chronic underfunding and wider social issues, it remained evident that physical factors were found to proliferate unhealthy and unsustainable outcomes in schools. Furthermore, the visual disconnection between unsustainable buildings and poor investment was associated with conflating and delegitimizing the potential power of ecological learning around health and sustainability (Chapman, 2012*; Dolan, Sturm, \& Wollmuth, 2006*; Zepatou, Loizidou, Chaloulakou, \& Spyrellis, 2016*).

\section{Ecologically focused policy}

Policies that encouraged walking and cycling were also considered to be indicators of health and environmental awareness with respect to schools. The importance of walking school buses (WSBs) and collaboration between local authorities and schools to improve the safety of surrounding streets (Kingham and Ussher, 2005*) was noted in the literature $(\mathrm{N}=6)$. Increasing the number of designated cycle paths and altering speed limits were important considerations when encouraging children to walk, cycle, or scoot to school (Helbich, 2017*). WSBs were found to have some success in encouraging children to choose healthy and environmentally conscious commutes to school, but success was often dependent on volunteer availability, which was often sporadic and difficult to maintain (Collins \& Kearns, 2010*; Hinckson, 2016*). Environmentally informed food policies were also found to be practical, healthy, and sustainable initiatives for schools to consider, with perceived benefits including cost-effectiveness, better nutrition from locally grown organic suppliers (including school- or communitybased gardens), and the lowering of the carbon footprint by choosing regional options 
(He \& Mikkelsen, 2014*; Liu et al., 2016*; Ribal et al., 2016*; Rojas et al., 2011*).

\section{Whole-school approaches}

Whole-school approaches consisted of strategies that went beyond a focus on the types of pedagogy used or the redesigning of more environmentally friendly spaces. Wholeschool approaches included embedding knowledge, competencies, and values that nurture healthier children and environments over time. These holistic approaches were often associated with challenging underlying anthropocentric assumptions through exploring the connections between environment, health, and behavior. Whole-school approaches also described an iterative process of change by applying a critical and reflective lens, which enabled schools to reimagine a school's ethos and approach. However, texts that spoke of reorienting the focus of schooling toward a deeper awareness and action competence around health and sustainability were largely examples of outlier perspectives in this sample (Davis \& Cooke, 2007*; Deep Green Bush-School, n.d.*; Dolan et al., 2006*; O’Brien \& Howard, 2016*). New Zealand's Enviroschools initiative, which is currently embedded to various degrees in over 1,000 schools, was found to be the most comprehensive and far-reaching holistic approach.

Enviroschools is a local government-funded initiative that works collaboratively with schools (Enviroschools.nz, 2019). Facilitators provide support, ideas, resources, and scaffolding for schools to think about how they can become more environmentally aware in ways that are meaningful to their own context and community (Jackson, 2009*; Williams, 2012*). The approach uses an underlying socioecological model of interacting systems combined with an action-based learning cycle to ensure integration of sustainability across all issues pressing to schools, including wellbeing, health, and environmental preservation and restoration (Enviroschools, 2017*). 


\section{Underlying theoretical frameworks and reported impacts}

Theory

A key theory found to underpin health and environmental integration was socioecological theory (Bronfenbrenner, 1979). This theory forms the foundation of the WHO's Health-Promoting Schools framework, which refers to links between environment and health after the Bangkok Charter (WHO, 1986, 2005b). Theoretical discussion around the need for a holistic reorientation of education toward futurefocused competencies was found across the literature $(\mathrm{n}=13)$. A subsample of articles and books provided logic models conceptualizing how schools can facilitate health and environmental integration $(n=8)$. Logic models presented the role of outdoor education as a potential universal health strategy (Pryor et al., 2005*) and the role of school gardens in facilitating health and environmental engagement (Ozer, 2006*; Wolsey and Lapp, 2014*). A pedagogical rationale for sustainability and health education was described that forms the basis for a project being undertaken by Swedish researchers titled 'From our beginnings to our futures’ (Jönköping University, 2019*).

\section{Evaluation of impacts}

We also used this systematic scoping review to explore whether any integrated approaches have been formally evaluated. Of the empirical research captured in the review, 38 papers (44\%) reported some form of outcome evaluation. Self-reported behavioral outcomes represented the largest proportion of findings associated with integrated activities. Findings included perceived higher levels of nutrition in children whose schools cultivated and consumed produce from on-site or community gardens (Dyg \& Wistoft, 2018*; Guitart et al., 2014*), improvements in children's subjective wellbeing (Black et al., 2015*; Maller \& Townsend, 2006*; Maller, Townsend, Pryor, 
Brown, \& St Leger, 2006*; Poland \& Dooris, 2010*; Pryor et al., 2005*), confidence, and motivation (Eames et al., 2008*; Kemp \& Pagden, 2018*; O’Brien, 2009*) after taking part in integrated or ecologically designed activities. Such approaches were also found to develop an individual's ability to carry out strategies for change in relation to environmental concerns (Bywater, 2014*; Dyg \& Wistoft, 2018*; Jones et al., 2012*; Keselman et al., 2012*; Lysgaard \& Simovska, 2016*; Simovska \& Mannix McNamara, 2015*). Evaluators of Enviroschools found that after a period of exposure to the approach, teachers reported positive increases in children's learning and wellbeing as well as positive rates of school environmental engagement, such as actions for sustainable transport and energy conservation actions (Enviroschools, 2017*).

Several studies examined the benefits to student and staff health from greening school buildings (Chapman, 2012*; Curwood, 2009*; Kensler \& Uline, 2016*; Theodosiou \& Ordoumpozanis, 2008*). The potential for schools to increase natural lighting and window size to improve ventilation and hence air quality, the use of solar panels to decrease economic and environmental costs, and the use of less toxic cleaning agents in and around schools were linked to possible improvements in the health of children and staff by limiting exposure to toxins and the inhalation of poor quality air (Brodie, 2009*; Heinze, 2010*; Theodosiou \& Ordoumpozanis, 2008*).

To summarize, while some potential benefits to integrated approaches were apparent in the literature, these were largely self-reported and of an observational nature (Dyg \& Wistoft, 2018*; Turtle et al., 2015*). A large degree of the research stipulated the need for further exploration to gain insights into effective ways of promoting environmental and health literacies, how to measure impacts (Kemp \& Pagden, 2018*; Zimmerman \& Weible, 2017*), and issues of transferability across various contexts (Black et al., 2015*; Kensler \& Uline, 2016*; Simovska \& Mannix McNamara, 2015*). 
Overall, the evidence captured in this review was found to be fragmented, with several aspects of integration in the school environment underexplored.

\section{Discussion}

This systematic scoping review mapped an emerging evidence base around the integration of approaches aimed at nurturing healthier and more environmentally aware young people through adaptation or intervention in the school context. We found a steady increase in publications since 1998, published mainly in North America, Australasia, and Northern Europe. The approaches largely fall under the categories of teaching and learning, physical environmental adaptations, ecologically informed policy development (such as those related to food and transport), and whole-school socioecological approaches. We found that the evidence utilized a range of theory, most notably socio-ecological and systems related and that evidence described a promising range of positive associated outcomes. Further examination of outcomes is necessary however, in order to better understand the factors and processes associated with impacts.

\section{Integration: key insights}

We took the following key learnings from our scoping review. Firstly, despite global policy communicating a more nuanced understanding of the connections between health and sustainability over the previous two decades, there is little comprehensive evidence yet of how global policy has had an impact on integrative practice in the school context. The WHO's Bangkok Charter for Health Promotion from 2005, which made explicit links to environmental sustainability, and the UN's decade of Education for Sustainable Development (WHO, 2005b; Buckler \& Creech, 2014) are examples of global agendas that describe both the importance of community settings, such as schools, in mitigating 
global health and environmental issues and the role of holistic approaches in nurturing associated ecological health knowledge and behaviors. Furthermore, the 17 goals put forward by the 2030 Agenda for Sustainable Development, adopted by all UN member states in 2015, clearly advocate health and environmental action across all systems of society and may also justify further research around integration in the school context (UN, 2019). However, alongside little substantive examination of impact in the school context, further critical synthesis about how paradigmatic assumptions across global policy shape the problematization of issues is necessary. This may ensure that policy and subsequent agendas are held to account for either challenging or maintaining unstainable practices and behaviors associated with the environment and human health (Buckler \& Creech, 2014; Huckle \& Wals, 2015; Bacchi, 2016).

Our second key area of learning related to the fragmented nature of the evidence as a whole and the inconsistent depth and clarity of the explanations of how conceptual frameworks were applied that were provided across the evidence. This requires further examination, and in light of the recognition that complex interventions and robust research, participatory or otherwise, should always be underpinned by clear theoretical frameworks, this could be a problematic characteristic of the existing evidence (Michie et al., 2005; McQueen \& Jones, 2007; Craig et al., 2008). We found that socioecological and systems theory underpinned many holistic approaches (Lewis \& Baudains, 2007*; Rojas et al., 2011*). This supports the findings of previous systematic reviews of promoting health in schools that have been undertaken (Langford et al., 2015a) and the relationship between nature and children (Gill, 2011; Adams \& Savahl, 2017). There was also a diverse range of critical theories related to education and pedagogy, which included perspectives from across traditional paradigmatic spectrums. 


\section{Gap analysis and limitations}

There is inconsistent evidence as yet in terms of how knowledge and awareness around the competencies associated with integrated approaches can be developed in a wideranging and systematic way, particularly in early teacher training and ongoing professional development (Sadegholvad, Yeoman, Parrish, \& Worley, 2017*). There is also limited evidence about how (and indeed whether there is scope) to undertake holistic approaches on a national scale, which is particularly relevant in contexts where schools are facing many competing priorities and unprecedented pressures.

While our review was comprehensive, it was not exhaustive, and further evidence, particularly among the wider grey literature, may have been missed. Further examination of the particular strengths and weaknesses of study designs in relation to the multifaceted school context may communicate findings more clearly in terms of policy and practice. The diverse range of outcomes makes drawing conclusions about the impact of integration difficult. The nature of what constitutes evidence across public health, education, and environmental sustainability is still contested and therefore further research is necessary to explore boundaries and synergies between evidence (Raphael, 2000; Craig et al., 2008; Kopnina, 2012b). This examination would also build on the work of Rowling and Jeffreys, who proposed that a weakness of the design of healthy school strategies was the limited integration of theory and evidence that draws on educational disciplinary perspectives, as well as health promotion (2006).

We noted diversity in how nature was defined, varying from more anthropocentric notions to theories of social nature that challenge what in wider literature is often argued to be a false binary between human society and nature (Castree \& MacMillan, 2001; Bell et al., 2019). Similarly, the concepts of environmental sustainability and health differed. We found that utilizing our chosen WHO definition 
(1986, p. 1) missed out on some conceptualizations of health, such as those used by researchers in health-related research disciplines who may choose to use the terms resilience or wellbeing rather than health or health behaviors. In relation to interdisciplinary review questions exploring health and sustainability in school settings, making sure that diverse terminology and an understanding of the various paradigms that shape the problematization of health and environmental challenges are incorporated throughout may ensure greater inclusivity of diverse research (Levac \& Denis, 2019). This may actively illumine new relationships and generate valuable learning. For further thinking around reflexivity in the design of inter-disciplinary research, see the work of (Sterling, 2010a, 2010b, 2014; Zeyer \& Kyburz-Graber, 2012), which provides valuable insights around potential next steps for overcoming emerging challenges associated with interdisciplinary research, policy, and practice.

The search strategy utilized was intentionally broad, though time and resources prohibited additional searches of further databases and forward and backward screening of all 87 texts. However, we are confident that the methods used demonstrate the variety of approaches and evidence across this emerging, interdisciplinary field. Due to pragmatic considerations, the searches were limited to English language literature,

which may have missed concepts and programs published in other languages. While data extraction was only intended to record general characteristics for each text, we have been able to give an overview of the extent and range of evidence associated with health and environmental sustainability integration in the school context, which serves as a starting point for further in-depth exploration and appraisal of evidence.

\section{Recommendations for policy, practice, and research}

While this review describes a growing volume of evidence detailing how integration has been approached globally over the past twenty years, there has not yet been any 
systematic evaluation of the evidence in terms of the processes and outcomes of these approaches. Further synthesis of the evidence may enable greater understanding of the factors or mechanisms associated with integration. These areas of further inquiry would deepen understanding around the conceptual argument for combining health-promoting and environmental sustainability approaches, specifically around the strengths and limitations of this thinking (Davis \& Cooke, 2007; Simovska \& Mannix McNamara, 2015) and may further expand upon the notion of integration as a means of transforming educational paradigms and systems more comprehensively (Sterling, 2003; Barnett, 2004; Berners-Lee, 2019).

The sparse research on integration in some regions, such as the UK, raises uncertainty about the universal understanding of the relationships between these agendas and about how associated disciplines (beyond public health and education) perceive relationships between the environment and human health more broadly (Barton \& Upadhyay, 2010; Buxton, 2010; Zeyer \& Kyburz-Graber, 2012). Further synthesis of the rationales and processes underpinning integrated approaches may inform an understanding of the next steps for integration in the school context from a global multidisciplinary perspective. This would also contribute to a much-needed discourse that would build on the work of Sterling (2013, 2014), Biesta (2009) and others on how education and its multiplicity of determinants is shaped and impacted at the interface between health, environmental and science education, systems thinking, and sustainability.

Important focal populations apart from children who are recognized in the review literature include education and public health providers, who can learn a great deal from collaborating with each other in terms of understanding the dynamic relationships between health and environmental concerns (Elsden-Clifton \& Futter- 
Puati, 2015*; Saaranen et al., 2015*; Mandikonza \& Lotz-Sisitka, 2016*; Norðdahl \& Jóhannesson, 2016*). This focus is echoed in wider literature by those who argue that research on school health promotion rarely includes paying attention to the core processes of schools, namely teaching and learning (Gugglberger et al., 2017, p. 163). The evidence suggests that this may be changing, and the potential outcomes from this greater engagement with the nonlinear process of making sense of the world that children encounter are encouraging (Kopnina, 2012b). By recognizing the process of learning and the critical roles that teachers and other school-based professionals play, the design and implementation of future approaches to a healthier and greener education may be more attuned to the daily challenges faced by schools (Jourdan et al., 2011; Hung et al., 2014; Huckle, 2014).

Experiential case studies that concern the implications for schools in light of context-specific barriers (such as time, resources, and funding) were limited. However, given the negative impacts of environmental degradation and chronic NCDs that disproportionately affect the poorest children, there is a critical need to explore what works for schools across economic and social spectrums (Barouki et al., 2012; Butler, 2016; A. McMichael \& Beaglehole, 2000; A. J. McMichael et al., 2008). Further case studies that examine how schools located in areas impacted most adversely by climate change and NCDs, for example, may capture changing priorities, including community approaches to tackling these issues, which may highlight avenues that can be pursued to support those schools.

The role of contextually rich data, which includes the participation of children, is necessary to shape the future of healthy green school settings through an active discourse of challenging assumptions, values, and behaviors that are intertwined with issues relating to the environment and human health (Kopnina, 2012b; Simovska, 
2012). In terms of framework development, this would advocate a balance between frameworks that provide direction and guidance and a level of flexibility that is enough for schools to shape their own approaches. This balance has been difficult to establish and sustain (Madsen et al., 2016), but it remains necessary in the endeavor to meet the needs of diverse school communities.

\section{Conclusion}

No areas of integration are well understood. The development of a critical discourse around the importance of an integrative health and environmental education in schools was evident in the literature, although the extent to which this has influenced practice so far is largely unknown. Given the worsening rates of NCDs and climate change, the importance of the intersection between health and environmental practice in schools is likely to become more significant. Therefore, further research on the mechanisms, variables, and processes described in the literature is needed to reveal important factors associated with how these components work in various contexts, who they work for, and how various focal populations within school contexts, such as leadership, teachers, and others, would like to be supported. Research that examines the in-depth experiences of particular areas or populations in schools would offer novel contextual insights, which would be especially valuable due to the difficulty in generalizing practice across the wider spectrum of schools (Young, 2015, p. 37). 


\section{References}

Adams, S., \& Savahl, S. (2017). Nature as children's space: A systematic review. The Journal of Environmental Education, 48(5), 291-321. https://doi.org/10.1080/00958964.2017.1366160

Ahn, Y. H., Choi, Y. O., Koh, B. W., \& Pearce, A. R. (2011). Designing Sustainable Learning Environments: Lowering Energy Consumption in a K-12 Facility. Journal of Green Building, 6(4), 112-137. https://doi.org/10.3992/jgb.6.4.112

Anderson, A. (2012). Climate Change Education for Mitigation and Adaptation. Journal of Education for Sustainable Development, 6(2), 191-206. https://doi.org/10.1177/0973408212475199

Arksey, H., \& O’Malley, L. (2005). Scoping studies: Towards a methodological framework. International Journal of Social Research Methodology, 8(1), 19-32. https://doi.org/10.1080/1364557032000119616

Bacchi, C. (2016). Problematizations in Health Policy: Questioning How "Problems" Are Constituted in Policies. SAGE Open, 6(2), 2158244016653986. https://doi.org/10.1177/2158244016653986

Barnett, R. (2004). Learning for an unknown future. Higher Education Research \& Development, 23(3), 247-260. https://doi.org/10.1080/0729436042000235382

Barouki, R., Gluckman, P. D., Grandjean, P., Hanson, M., \& Heindel, J. J. (2012). Developmental origins of non-communicable disease: Implications for research and public health. Environmental Health, 11, 42. https://doi.org/10.1186/1476069X-11-42

Barrett, M. J. (2006). Education for the environment: Action competence, becoming, and story. Environmental Education Research, 12(3-4), 503-511. https://doi.org/10.1080/13504620600799273 
Barton, A. C., \& Upadhyay, B. (2010). Teaching and Learning Science for Social Justice: Introduction to the Special Issue. Equity \& Excellence in Education, 43(1), 1-5. https://doi.org/10.1080/10665680903484917

Bell, S. L., Leyshon, C., Foley, R., \& Kearns, R. A. (2019). The "healthy dose" of nature: A cautionary tale. Geography Compass, 13(1), e12415. https://doi.org/10.1111/gec3.12415

Berners-Lee, M. (Ed.). (2019). There Is No Planet B: A Handbook for the Make or Break Years. In There Is No Planet B: A Handbook for the Make or Break Years (pp. i-i). Cambridge University Press; Cambridge Core. https://www.cambridge.org/core/books/there-is-no-planet-b/there-is-no-planetb/061D0E55B6A60BD1D52ED499589EE1E8

Biesta, G. (2009). Good education in an age of measurement: On the need to reconnect with the question of purpose in education. Educational Assessment, Evaluation and Accountability(Formerly: Journal of Personnel Evaluation in Education), 21(1), 33-46. https://doi.org/10.1007/s11092-008-9064-9

Birney, A., \& Reed, J. (2009). Sustainability and renewal: Findings from the Leading Sustainable Schools research project. National College for Leadership of Schools and Children's Services. https://core.ac.uk/download/pdf/4152267.pdf

Black, J. L., Velazquez, C. E., Ahmadi, N., Chapman, G. E., Carten, S., Edward, J., Shulhan, S., Stephens, T., \& Rojas, A. (2015). Sustainability and public health nutrition at school: Assessing the integration of healthy and environmentally sustainable food initiatives in Vancouver schools. Public Health Nutrition, 18(13), 2379-2391. https://doi.org/10.1017/S1368980015000531 
Bonnett, M. (1999). Education for Sustainable Development: A coherent philosophy for environmental education? Cambridge Journal of Education, 29(3), 313-324. https://doi.org/10.1080/0305764990290302

Breiting, S., \& Mogensen, F. (1999). Action Competence and Environmental Education. Cambridge Journal of Education, 29(3), 349-353. https://doi.org/10.1080/0305764990290305

Brodie, J. (2009). Putting the wind and sun to work: Sustainable design in schools. Teacher, 200, 14-16,18.

Bronfennbrenner, U. (1979). The Ecology of Human Development (1st ed.). Harvard University Press.

Buckler, C., \& Creech, H. (2014). Shaping the future we want: UN Decade of Education for Sustainable Development. United Nations. https://unesdoc.unesco.org/ark:/48223/pf0000230171

Butler, C. D. (2016). Sounding the Alarm: Health in the Anthropocene. International Journal of Environmental Research and Public Health, 13(7), 665. https://doi.org/10.3390/ijerph13070665

Buxton, C. A. (2010). Social Problem Solving Through Science: An Approach to Critical, Place-Based, Science Teaching and Learning. Equity \& Excellence in Education, 43(1), 120-135. https://doi.org/10.1080/10665680903408932

Bybee, R. W. (2012). Scientific Literacy in Environmental and Health Education. In A. Zeyer \& R. Kyburz-Graber (Eds.), Science | Environment | Health: Towards a Renewed Pedagogy for Science Education (pp. 49-67). Springer Netherlands. https://doi.org/10.1007/978-90-481-3949-1_4

Bywater, K. (2014). Investigating the Benefits of Participatory Action Research for Environmental Education. Policy Futures in Education, 12(7), 920-932. 
Carley, F.-M., Fisher, D. R., \& Ray, R. (2018). Can learning in informal settings mitigate disadvantage and promote urban sustainability? School gardens in Washington, DC. International Review of Education / Internationale Zeitschrift Für Erziehungswissenschaft, 64(3), 295-312. https://doi.org/10.1007/s11159017-9663-0

Castree, N., \& MacMillan, T. (2001). Dissolving Dualisms: Actor-networks and the Reimagination of Nature. In Social Nature: Theory, Practice, and Politics (1st ed.). Blackwell Publishing Ltd.

Chapman, P. (2012). THE BENEFITS OF GREEN SCHOOLS. Independent School, 72(1), 40-47.

Collins, D., \& Kearns, R. A. (2010). Walking school buses in the Auckland region: A longitudinal assessment. Transport Policy, 17(1), 1-8. https://doi.org/10.1016/j.tranpol.2009.06.003

Colquhoun, H. L., Levac, D., O’Brien, K. K., Straus, S., Tricco, A. C., Perrier, L., Kastner, M., \& Moher, D. (2014). Scoping reviews: Time for clarity in definition, methods, and reporting. Journal of Clinical Epidemiology, 67(12), 1291-1294. https://doi.org/10.1016/j.jclinepi.2014.03.013

Craig, P., Dieppe, P., Macintyre, S., Michie, S., Nazareth, I., \& Petticrew, M. (2008). Developing and evaluating complex interventions: The new Medical Research Council guidance. BMJ, 337. https://doi.org/10.1136/bmj.a1655

Curwood, J. S. (2009). Why Green Schools Matter. Scholastic Administrator, 8(7), 3841.

Cutter-Mackenzie, A. (2009). Multicultural School Gardens: Creating Engaging Garden Spaces in Learning about Language, Culture, and Environment. Canadian Journal of Environmental Education, v14, p122-135. 
Dadaczynski, K., Jensen, B. B., Viig, N. G., Sormunen, M., von Seelen, J., Kuchma, V., \& Vilaça, M. T. (2019). Health, well-being and education: Building a sustainable future.The Moscow Statement on Health Promoting Schools. Schools for Health in Europe. https://www.schoolsforhealth.org/sites/default/files/editor/conference\%20statem ents/the_moscow_statement_on_health_promoting_schools_short_version.pdf

Davis, J. M., \& Cooke, S. M. (2007). Educating for a healthy, sustainable world: An argument for integrating health promoting schools and sustainable schools. Health Promotion International, 22(4), 346-353. https://doi.org/10.1093/heapro/dam030

Deep Green Bush-School. (2018). Who we are. Deep Green Bush-School. http://www.deepgreenbushschool.org/who-we-are.html

DfE. (2009). Sustainable Schools National Framework. Department for Education Archives; The National Archives. https://webarchive.nationalarchives.gov.uk/20090326035839/http://www.teache rnet.gov.uk/sustainableschools/library/programme/library_programmes.cfm

Dillon, J. (2012). Science, Environment and Health Education: Towards a Reconceptualisation of Their Mutual Interdependences. In A. Zeyer \& R. Kyburz-Graber (Eds.), Science | Environment | Health: Towards a Renewed Pedagogy for Science Education (pp. 87-101). Springer Netherlands. https://doi.org/10.1007/978-90-481-3949-1_6

Dolan, P., Sturm, B., \& Wollmuth, C. (2006). Prairie Crossing Charter School: Comfort as a Principal Component of High Performance School Design. Journal of Green Building, 1(3), 17-25. https://doi.org/10.3992/jgb.1.3.17 
Dyg, P. M., \& Wistoft, K. (2018). Wellbeing in school gardens - the case of the Gardens for Bellies food and environmental education program. Environmental Education Research, 24(8), 1177-1191. https://doi.org/10.1080/13504622.2018.1434869

Eames, C., Cowie, B., \& Bolstad, R. (2008). An evaluation of characteristics of environmental education practice in New Zealand schools. Environmental Education Research, 14(1), 35-51. https://doi.org/10.1080/13504620701843343

Eco Schools. (2020, March 22). Home. Eco Schools. https://www.eco-schools.org.uk/ Edwards, S., Skouteris, H., Cutter-Mackenzie, A., Rutherford, L., O’Conner, M., Mantilla, A., Morris, H., \& Elliot, S. (2016). Young children learning about well-being and environmental education in the early years: A funds of knowledge approach. Early Years, 36(1), 33-50. https://doi.org/10.1080/09575146.2015.1064099

Elsden-Clifton, J., \& Futter-Puati, D. (2015). Creating a Health and Sustainability Nexus in Food Education: Designing Third Spaces in Teacher Education. Australian Journal of Environmental Education, 31(1), 86-98. https://doi.org/10.1017/aee.2014.44

Enviroschools. (2017). Enviroschools-Key findings from the Nationwide Census. 44.

Frech, A. (2012). Healthy Behavior Trajectories between Adolescence and Young Adulthood. Advances in Life Course Research, 17(2), 59-68. https://doi.org/10.1016/j.alcr.2012.01.003

Gill, T. (2011). Children and nature: A quasi -systematic review of the empirical evidence. London Sustainable Development Commission. https://www.academia.edu/5775760/Children_and_nature_A_quasi_systematic_review_of_the_empirical_evidence 
Green, M. (2013). Place matters: Pedagogies of food, ecology and design.

Environmental Education Research, 19(2), 252-253.

https://doi.org/10.1080/13504622.2012.697546

Green Schools Alliance. (2020). Green Schools Alliance. Green Schools Alliance. https://www.greenschoolsalliance.org/home

Gugglberger, L., Flaschberger, E., \& Teutsch, F. (2017). "Side effects" of health promotion: An example from Austrian schools. Health Promotion International, 32(1), 157-166. https://doi.org/10.1093/heapro/dau054

Guitart, D. A., Pickering, C. M., \& Byrne, J. A. (2014). Color me healthy: Food diversity in school community gardens in two rapidly urbanising Australian cities. Health \& Place, 26, 110-117. https://doi.org/10.1016/j.healthplace.2013.12.014

Halfon, N., \& Hochstein, M. (2002). Life Course Health Development: An Integrated Framework for Developing Health, Policy, and Research. The Milbank Quarterly, 80(3), 433-479. https://doi.org/10.1111/1468-0009.00019

Harris, A. (2008). Leading Sustainable Schools. Specialist Schools and Academies Trust. http://www.bath.ac.uk/cree/Leading_Sustainable_Schools_130361.pdf

Harris, B. (1995). Health of the Schoolchild: History of the School Medical Service in England and Wales, 1908-74 (1st ed.). Open University Press.

Hawkes, C. (2007). Promoting healthy diets and tackling obesity and diet-related chronic diseases: What are the agricultural policy levers? Food and Nutrition Bulletin, 28(2 Suppl), S312-322. https://doi.org/10.1177/15648265070282S210

He, C., \& Mikkelsen, B. E. (2014). The association between organic school food policy and school food environment: Results from an observational study in Danish 
schools. Perspectives in Public Health, 134(2), 110-116.

https://doi.org/10.1177/1757913913517976

Head, B. W., \& Alford, J. (2015). Wicked Problems: Implications for Public Policy and Management. Administration \& Society, 47(6), 711-739. https://doi.org/10.1177/0095399713481601

Heinze, J. (2010). Q\&A: Schooling for sustainability. Scholastic Administrator, 10, 5657.

Helbich, M. (2017). Children's school commuting in the Netherlands: Does it matter how urban form is incorporated in mode choice models? International Journal of Sustainable Transportation, 11(7), 507-517. https://doi.org/10.1080/15568318.2016.1275892

Hinckson, E. (2016). Perceived challenges and facilitators of active travel following implementation of the School Travel-Plan programme in New Zealand children and adolescents. Journal of Transport \& Health, 3(3), 321-325. https://doi.org/10.1016/j.jth.2016.05.126

Holloway, S. L., \& Valentine, G. (2004). Children's Geographies: Playing, Living, Learning. Routledge. https://doi.org/10.4324/9780203017524

Huckle, J. (2014). Teacher Education. In Education for Sustainability (Ebook, pp. 105120). Earthscan.

Huckle, J., \& Wals, A. E. J. (2015). The UN Decade of Education for Sustainable Development: Business as usual in the end. Environmental Education Research, 21(3), 491-505. https://doi.org/10.1080/13504622.2015.1011084

Hung, T. T. M., Chiang, V. C. L., Dawson, A., \& Lee, R. L. T. (2014). Understanding of Factors that Enable Health Promoters in Implementing Health-Promoting 
Schools: A Systematic Review and Narrative Synthesis of Qualitative Evidence. PLoS ONE, 9(9). https://doi.org/10.1371/journal.pone.0108284

Ikeda, E., Stewart, T., Garrett, N., Egli, V., Mandic, S., Hosking, J., Witten, K., Hawley, G., Tautolo, E. S., Rodda, J., Moore, A., \& Smith, M. (2018). Built environment associates of active school travel in New Zealand children and youth: A systematic meta-analysis using individual participant data. Journal of Transport \& Health, 9, 117-131. https://doi.org/10.1016/j.jth.2018.04.007

Jackson, S. (2009). Enviroschools in New Zealand. MAI Review, 1.

Jensen, B. B., \& Schnack, K. (1997). The Action Competence Approach in Environmental Education. Environmental Education Research, 3(2), 163-178. https://doi.org/10.1080/1350462970030205

Jickling, B. (2001). Environmental Thought, the Language of Sustainability, and Digital Watches. Environmental Education Research - ENVIRON EDUC RES, 7, 167180. https://doi.org/10.1080/13504620120043171

Jickling, B., \& Wals, A. E. J. (2008). Globalization and environmental education:

Looking beyond sustainable development. Journal of Curriculum Studies, 40(1), 1-21. https://doi.org/10.1080/00220270701684667

Jones, M., Weitkamp, E., Kimberlee, R., Salmon, D., \& Orme, J. (2012). Realizing a Holistic Approach to Food through School Gardens and Growing Activities. Children, Youth \& Environments, 22(1), 75-98.

Jönköping University. (2019, May 21). Sustainability Education Research. Sustainability Education Research. https://ju.se/forskning/forskningsinriktningar/larandepraktiker-i-och-utanforskolan-lps/sustainability-education-research-ser.html 
Jourdan, D., Stirling, J., Mannix Mcnamara, P., \& Pommier, J. (2011). The influence of professional factors in determining primary school teachers' commitment to health promotion. Health Promotion International, 26(3), 302-310. https://doi.org/10.1093/heapro/daq076

Jrgensen, K.-A. (2017). Storied Landscapes: Children's Experiences and the 'Sense' of Place. In The SAGE Handbook of Outdoor Play and Learning (pp. 609-629). SAGE Publications Ltd. https://doi.org/10.4135/9781526402028

Kagawa, F., \& Selby, D. (2010). Education and Climate Change: Living and Learning in Interesting Times (1st ed.). Routledge.

Kahn, P. H., \& Kellert, S. R. (2002). Children and Nature: Psychological, Sociocultural, and Evolutionary Investigations. MIT Press.

Kaplan, R., \& Kaplan, S. (1989). The experience of nature: A psychological perspective. Cambridge ; New York : Cambridge University Press. http://archive.org/details/experienceofnatu00kapl

Kellert, S. R., \& Wilson, E. O. (1993). The Biophilia Hypothesis. Island Press.

Kemp, N., \& Pagden, A. (2018). The place of forest school within English primary schools: Senior leader perspectives. Education 3-13, O(0), 1-13. https://doi.org/10.1080/03004279.2018.1499791

Kemple, K. M., Oh, J., Kenney, E., \& Smith-Bonahue, T. (2016). The Power of Outdoor Play and Play in Natural Environments. Childhood Education, 92(6), 446-454. https://doi.org/10.1080/00094056.2016.1251793

Kensler, L. A. W., \& Uline, C. L. (2016). Leadership for Green Schools: Sustainability for Our Children, Our Communities, and Our Planet. Taylor \& Francis.

Keselman, A., Levin, D. M., Hundal, S., Kramer, J. F., Matzkin, K., \& Dutcher, G. (2012). Teaching Environmental Health Science for Informed Citizenship in the 
Science Classroom and Afterschool Clubs. The International Journal of Science in Society, 3(3), 31-44.

King, E. W., \& Kahn, P. H. (2003). Children and Nature: Psychological, Sociocultural, and Evolutionary Investigations. Contemporary Sociology, 32(6), 733-734. JSTOR. https://doi.org/10.2307/1556666

Kopnina, H. (2012a). Education for sustainable development (ESD): The turn away from 'environment' in environmental education? Environmental Education Research, 18(5), 699-717. https://doi.org/10.1080/13504622.2012.658028

Kopnina, H. (2012b). 'People are not plants, but both need to grow': Qualitative analysis of the new ecological paradigm scale for children. The Environmentalist, 32(4), 394-404. https://doi.org/10.1007/s10669-012-9401-X

Langford, R., Bonell, C., Jones, H., Pouliou, T., Murphy, S., Waters, E., Komro, K., Gibbs, L., Magnus, D., \& Campbell, R. (2015a). The World Health Organization's Health Promoting Schools framework: A Cochrane systematic review and meta-analysis. BMC Public Health, 15(1), 130. https://doi.org/10.1186/s12889-015-1360-y

Langford, R., Bonell, C., Jones, H., Pouliou, T., Murphy, S., Waters, E., Komro, K., Gibbs, L., Magnus, D., \& Campbell, R. (2015b). The World Health Organization's Health Promoting Schools framework: A Cochrane systematic review and meta-analysis. BMC Public Health, 15(1), 130. https://doi.org/10.1186/s12889-015-1360-y

Levac, L., \& Denis, A. B. (2019). Combining feminist intersectional and communityengaged research commitments: Adaptations for scoping reviews and secondary analyses of national data sets. Gateways: International Journal of Community 
Research and Engagement, 12(1), ID 6193-ID 6193.

https://doi.org/10.5130/ijcre.v12i1.6193

Lewicki, J. (1998). Cooperative Ecology \& Place: Development of a Pedagogy of Place Curriculum.

Lewis, E., \& Baudains, C. (2007). Whole systems thinking: Education for sustainability at a Montessori school. Eingana, 30(1), 9-11.

Liu, Y., Cheng, S., Liu, X., Cao, X., Xue, L., \& Liu, G. (2016). Plate Waste in School Lunch Programs in Beijing, China. Sustainability, 8(12), 1-11.

Louv, R. (2010). Last Child in the Woods: Saving Our Children From a Nature-Deficit Disorder (2nd ed.). Atlantic Books.

Lovell, R., Husk, K., Bethel, A., \& Garside, R. (2014). What are the health and wellbeing impacts of community gardening for adults and children: A mixed method systematic review protocol. Environmental Evidence, 3(1), 20.

https://doi.org/10.1186/2047-2382-3-20

Lysgaard, J. A., \& Simovska, V. (2016). The significance of 'participation' as an educational ideal in education for sustainable development and health education in schools. Environmental Education Research, 22(5), 613-630. https://doi.org/10.1080/13504622.2015.1029875

MacQuarrie, S., \& Nugent, C. (2017). Considering Children's Opportunities for Exploration of their Local Environment and Engagement with Nature1. In The SAGE Handbook of Outdoor Play and Learning (pp. 229-241). SAGE Publications Ltd. https://doi.org/10.4135/9781526402028

Madsen, K. D., Nordin, L. L., \& Simovska, V. (2016). Supporting Structures for Education for Sustainable Development and School-based Health Promotion. 
Journal of Education for Sustainable Development, 10(2), 274-288.

https://doi.org/10.1177/0973408216650955

Maller, C., \& Townsend, M. (2006). Children's mental health and wellbeing and; hands-on contact with nature. International Journal of Learning, 12,(4), 359372.

Maller, C., Townsend, M., Pryor, A., Brown, P., \& St Leger, L. (2006). Healthy nature healthy people: 'Contact with nature' as an upstream health promotion intervention for populations. Health Promotion International, 21(1), 45-54. https://doi.org/10.1093/heapro/dai032

Mandikonza, C., \& Lotz-Sisitka, H. (2016). Emergence of environment and sustainability education (ESE) in teacher education contexts in Southern Africa: A common good concern. Educational Research for Social Change, 5(1), 107130. https://doi.org/10.17159/2221-4070/2016/v5i1a7

McMichael, A., \& Beaglehole, R. (2000). The changing global context of public health. The Lancet, 356(9228), 495-499. https://doi.org/10.1016/S01406736(00)02564-2

McMichael, A. J., Friel, S., Nyong, A., \& Corvalan, C. (2008). Global environmental change and health: Impacts, inequalities, and the health sector. BMJ, 336(7637), 191-194. https://doi.org/10.1136/bmj.39392.473727.AD

McQueen, D. V., \& Jones, C. M. (2007). Global Perspectives on Health Promotion Effectiveness. In D. V. McQueen \& C. M. Jones (Eds.), Global Perspectives on Health Promotion Effectiveness (pp. 3-11). Springer. https://doi.org/10.1007/978-0-387-70974-1_1

Michie, S., Johnston, M., Abraham, C., Lawton, R., Parker, D., \& Walker, A. (2005). Making psychological theory useful for implementing evidence based practice: 
A consensus approach. BMJ Quality \& Safety, 14(1), 26-33.

https://doi.org/10.1136/qshc.2004.011155

Moher, D., Liberati, A., Tetzlaff, J., \& Altman, D. G. (2009). Preferred reporting items for systematic reviews and meta-analyses: The PRISMA statement. BMJ, 339, b2535. https://doi.org/10.1136/bmj.b2535

Norðdahl, K., \& Jóhannesson, I. Á. (2016). 'Let's go outside': Icelandic teachers' views of using the outdoors. Education 3-13, 44(4), 391-406. https://doi.org/10.1080/03004279.2014.961946

O’Brien, C., \& Howard, P. (2016). The Living School: The Emergence of a Transformative Sustainability Education Paradigm. Journal of Education for Sustainable Development, 10(1), 115-130.

O’Brien, L. (2009). Learning outdoors: The Forest School approach. Education 3-13, 37(1), 45-60. https://doi.org/10.1080/03004270802291798

Ohly, H., Gentry, S., Wigglesworth, R., Bethel, A., Lovell, R., \& Garside, R. (2016). A systematic review of the health and well-being impacts of school gardening: Synthesis of quantitative and qualitative evidence. BMC Public Health, 16(1), 286. https://doi.org/10.1186/s12889-016-2941-0

Poland, B., \& Dooris, M. (2010). A green and healthy future: The settings approach to building health, equity and sustainability. Critical Public Health, 20(3), 281298. https://doi.org/10.1080/09581596.2010.502931

Pryor, A., Carpenter, C., \& Townsend, M. (2005). Outdoor education and bush adventure therapy: A social-ecological approach to health and wellbeing. Australian Journal of Outdoor Education, 9(1), 3-13.

Raphael, D. (2000). The question of evidence in health promotion. Health Promotion International, 15(4), 355-367. https://doi.org/10.1093/heapro/15.4.355 
Ribal, J., Fenollosa, M. L., García-Segovia, P., Clemente, G., Escobar, N., \& Sanjuán, N. (2016). Designing healthy, climate friendly and affordable school lunches. The International Journal of Life Cycle Assessment, 21(5), 631-645. https://doi.org/10.1007/s11367-015-0905-8

Rojas, A., Valley, W., Mansfield, B., Orrego, E., Chapman, G. E., \& Harlap, Y. (2011). Toward Food System Sustainability through School Food System Change: Think\&EatGreen@School and the Making of a Community-University Research Alliance. Sustainability, 3(5), 763-788. https://doi.org/10.3390/su3050763

Rowling, L., \& Jeffreys, V. (2006). Capturing complexity: Integrating health and education research to inform health-promoting schools policy and practice. Health Education Research, 21(5), 705-718. https://doi.org/10.1093/her/cyl089 Saaranen, T., Tossavainen, K., Sormunen, M., Laine, S., \& Turunen, H. (2015). Developing and Testing a Health Promotion Theory-An Example of Creating a Model of School Staff's Occupational Well-being. In Schools for Health and Sustainability: Theory, Research and Practise (Vol. 1). Springer Science + Business Media Dordrecht.

Sadegholvad, S., Yeatman, H., Parrish, A.-M., \& Worsley, A. (2017). What Should Be Taught in Secondary Schools' Nutrition and Food Systems Education? Views from Prominent Food-Related Professionals in Australia. Nutrients, 9(11). https://doi.org/10.3390/nu9111207

SEEd. (2019). Sustainability and Environmental Education. Sustainability and Environmental Education Homepage. https://se-ed.co.uk/edu/ 
Simovska, V. (2012). Processes and outcomes in school health promotion: Engaging with the evidence discourse. Health Education, 112(3). https://doi.org/10.1108/he.2012.142112caa.001

Simovska, V., \& Mannix McNamara, P. (Eds.). (2015). Schools for Health and Sustainability. Springer Netherlands. https://doi.org/10.1007/978-94-017-9171-7

Simpson, K., \& Freeman, R. (2004). Critical health promotion and education-A new research challenge. Health Education Research, 19(3), 340-348. https://doi.org/10.1093/her/cyg049

Sterling, S. (2003). Whole systems thinking as a basis for paradigm change in education: Explorations in the context of sustainability [Ph.D., University of Bath]. https://ethos.bl.uk/OrderDetails.do?uin=uk.bl.ethos.413906

Sterling, S. (2010a, September 28). Sustainable Education. Science, Society and Sustainability; Routledge. https://doi.org/10.4324/9780203875124-18

Sterling, S. (2010b). Learning for resilience, or the resilient learner? Towards a necessary reconciliation in a paradigm of sustainable education. Environmental Education Research, 16(5-6), 511-528. https://doi.org/10.1080/13504622.2010.505427

Sterling, S. (2013, June 17). An Analysis of the Development of Sustainability Education Internationally: Evolution, Interpretation and Transformative Potential. The Sustainability Curriculum; Routledge. https://doi.org/10.4324/978184977328710

Sterling, S. (2014). Education in Change. In Education for Sustainability (Ebook, pp. 18-39). Earthscan.

Swinburn, B. A., Kraak, V. I., Allender, S., Atkins, V. J., Baker, P. I., Bogard, J. R., Brinsden, H., Calvillo, A., Schutter, O. D., Devarajan, R., Ezzati, M., Friel, S., 
Goenka, S., Hammond, R. A., Hastings, G., Hawkes, C., Herrero, M., Hovmand, P. S., Howden, M., ... Dietz, W. H. (2019). The Global Syndemic of Obesity, Undernutrition, and Climate Change: The Lancet Commission report. The Lancet, 393(10173), 791-846. https://doi.org/10.1016/S0140-6736(18)32822-8

The Rockefeller Foundation. (2019). Planetary Health. The Rockefeller Foundation. https://www.rockefellerfoundation.org/our-work/initiatives/planetary-health/ Theodosiou, T. G., \& Ordoumpozanis, K. T. (2008). Energy, comfort and indoor air quality in nursery and elementary school buildings in the cold climatic zone of Greece. Energy and Buildings, 40(12), 2207-2214. https://doi.org/10.1016/j.enbuild.2008.06.011

Toimata Foundation. (2020). Enviroschools. Enviroschools. https://enviroschools.org.nz/

Tricco, A. C., Lillie, E., Zarin, W., O’Brien, K. K., Colquhoun, H., Levac, D., Moher, D., Peters, M. D. J., Horsley, T., Weeks, L., Hempel, S., Akl, E. A., Chang, C., McGowan, J., Stewart, L., Hartling, L., Aldcroft, A., Wilson, M. G., Garritty, C., ... Straus, S. E. (2018). PRISMA Extension for Scoping Reviews (PRISMAScR): Checklist and Explanation. Annals of Internal Medicine, 169(7), 467. https://doi.org/10.7326/M18-0850

Turtle, C., Convery, I., \& Convery, K. (2015). Forest Schools and environmental attitudes: A case study of children aged 8-11 years. Cogent Education, 2(1), 1100103. https://doi.org/10.1080/2331186X.2015.1100103

UN. (1987). Our Common Future. United Nations; sustainabledevelopment.un.org. https://sustainabledevelopment.un.org/content/documents/5987our-commonfuture.pdf 
UN. (2019). Sustainable Development Goals. Sustainable Development Goals:

Knowledge Platform. https://sustainabledevelopment.un.org/sdgs

UNICEF. (2018). UNICEF Data: Monitoring the situation of children and women.

Primary Education. https://data.unicef.org/topic/education/primary-education/

Waite, S., Bølling, M., \& Bentsen, P. (2016). Comparing apples and pears?: A conceptual framework for understanding forms of outdoor learning through comparison of English Forest Schools and Danish udeskole. Environmental Education Research, 22(6), 868-892.

https://doi.org/10.1080/13504622.2015.1075193

Waters, P. (2017). Developing the Pedogogic Method Narrative Journey. In The SAGE Handbook of Outdoor Play and Learning (1st ed., pp. 446-464). SAGE Publications.

WHO. (1986). Ottawa Charter for Health Promotion. World Health Organization. https://www.who.int/healthpromotion/conferences/previous/ottawa/en/

WHO. (2005a). Health Effects of Transport-related Air Pollution. WHO Regional Office Europe.

WHO. (2005b). The Bangkok Charter for Health Promotion in a Globalized World (11 August 2005). The Bangkok Charter for Health Promotion in a Globalized World (11 August 2005). WHO Global Conference on Health Promotion, Bangkok. https://www.who.int/healthpromotion/conferences/6gchp/bangkok_charter/en/ WHO. (2017). WHO | One Health. WHO | One Health. https://www.who.int/features/qa/one-health/en/

Williams, A. J., Henley, W. E., Williams, C. A., Hurst, A. J., Logan, S., \& Wyatt, K. M. (2013). Systematic review and meta-analysis of the association between 
childhood overweight and obesity and primary school diet and physical activity policies. International Journal of Behavioral Nutrition and Physical Activity, 10(1), 101. https://doi.org/10.1186/1479-5868-10-101

Williams, P. (2012). Educating for Sustainability in New Zealand: Success Through Enviroschools. In M. Robertson (Ed.), Schooling for Sustainable Development: A Focus on Australia, New Zealand, and the Oceanic Region (pp. 33-48). Springer Netherlands. https://doi.org/10.1007/978-94-007-2882-0_3

Young, I. M. (2015). Health Promotion and Sustainable Development in Schools: Historical Perspective. In Schools for Health and Sustainability: Theory, Research and Practise (1st ed., pp. 19-40). Springer Science + Business Media Dordrecht.

Zepatou, V., Loizidou, M., Chaloulakou, A., \& Spyrellis, N. (2016). School Facilities and Sustainability-Related Concepts: A Study of Hellenic Secondary School Principals', Teachers', Pupils' and Parents' Responses. Sustainability, 8(4). https://doi.org/10.3390/su8040311

Zeyer, A., \& Dillon, J. (2014). Science|Environment|Health-Towards a reconceptualization of three critical and inter-linked areas of education. International Journal of Science Education, 36(9), 1409-1411. https://doi.org/10.1080/09500693.2014.904993

Zeyer, A., \& Kyburz-Graber, R. (Eds.). (2012). Science | Environment | Health: Towards a Renewed Pedagogy for Science Education (1st ed.). Springer Netherlands. https://doi.org/10.1007/978-90-481-3949-1

Zimmerman, H. T., \& Weible, J. L. (2017). Learning in and about rural places: Connections and tensions between students' everyday experiences and 
environmental quality issues in their community. Cultural Studies of Science

Education, 12(1), 7-31. https://doi.org/10.1007/s11422-016-9757-1

\section{Competing interests}

This research was conducted as part of a PhD funded by University of Exeter, College of Medicine and Health. The authors declare no competing interests. 


\section{Supplementary files}

(Figure 1: Flowchart of search process adapted from the PRISMA framework, Moher et al., 2009)

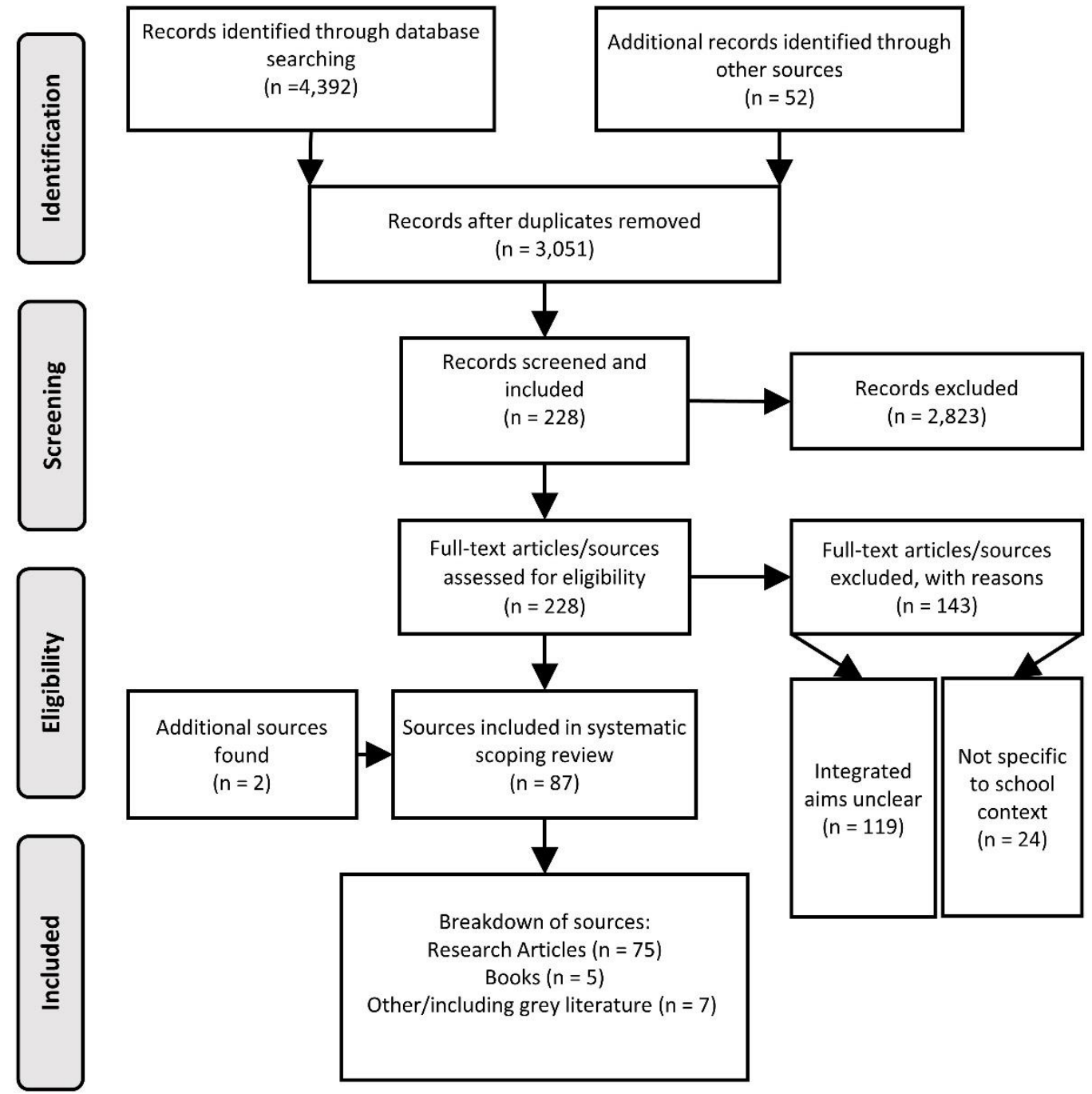


(Figure 2 Volume and timing of evidence $(\mathrm{N}=87)$ )

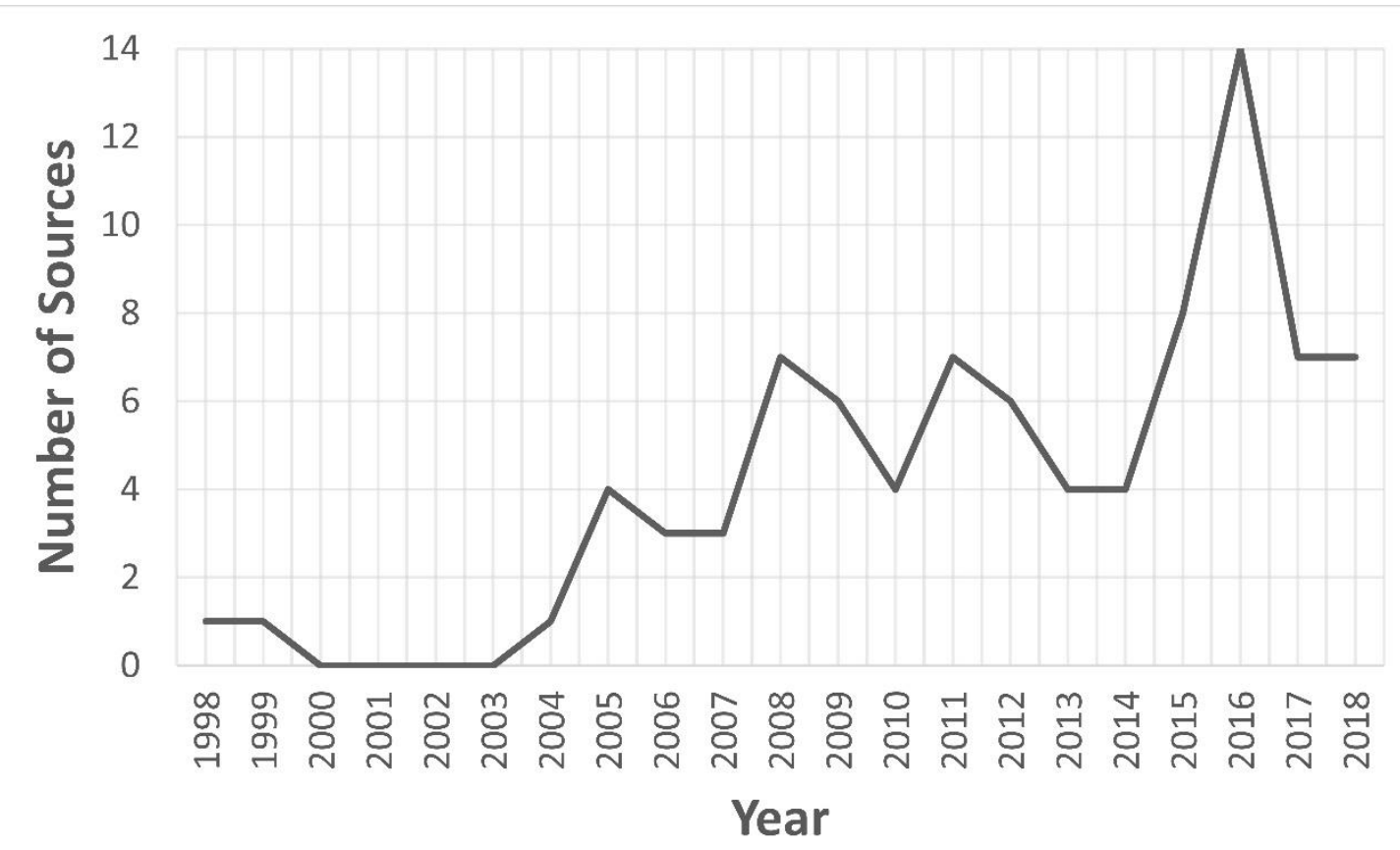


(Figure 3: Volume of evidence by region)

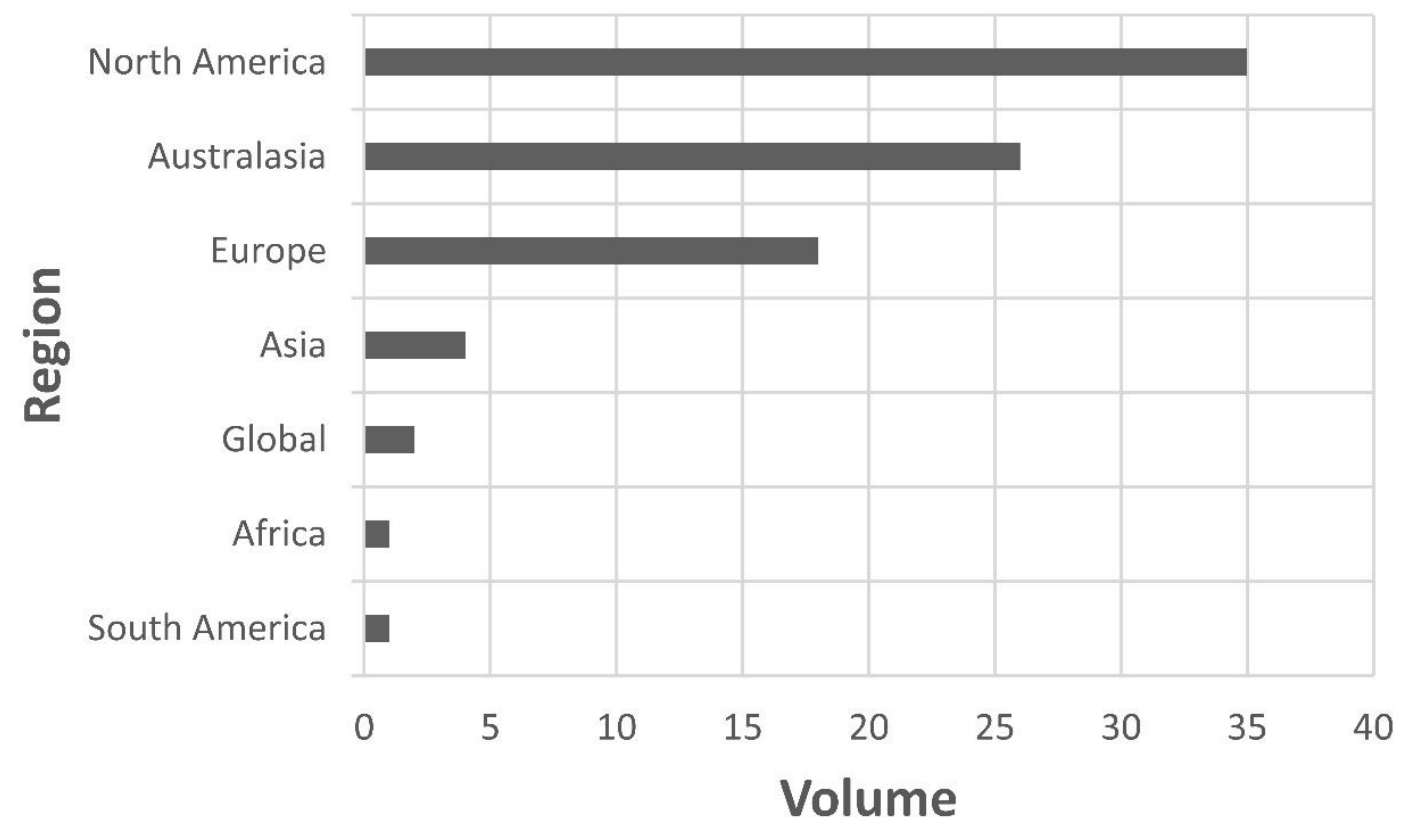


(Figure 4: Number of sources captured according to focus and region)

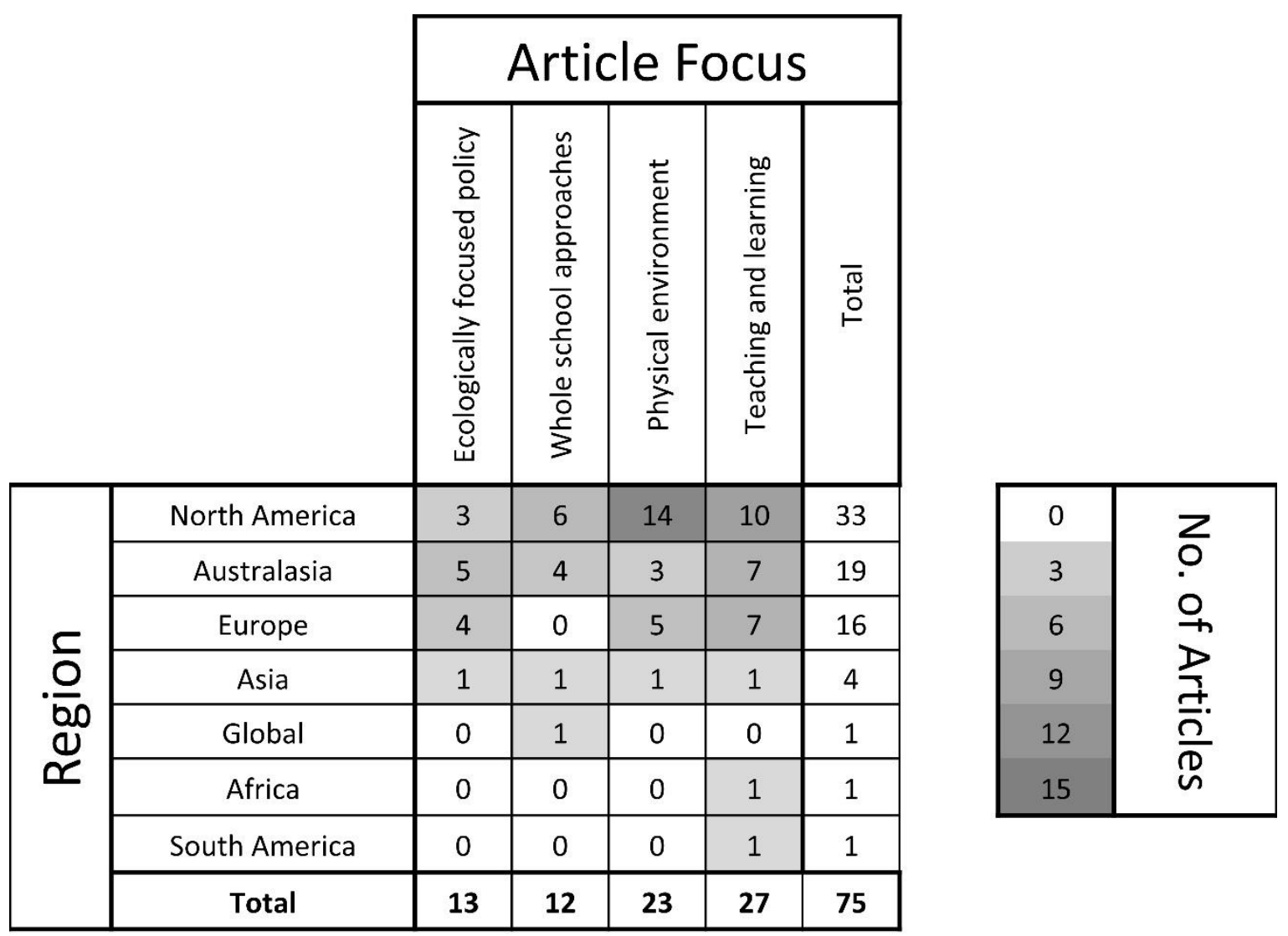

